\title{
What gets healed due to healing imagery? \\ Effectiveness of the Simonton method among Hungarian cancer patients
}

Background and aims: The Simonton technique, an intervention developed in the 1970's, was designed to improve the coping skills of cancer patients. This intervention aims to facilitate the processing of negative emotions and coping with changes caused by the disease; further, it empowers the conditions for a meaningful life. Our goal was to investigate the effectiveness of this intervention among Hungarian cancer patients.

Methods: The sample $(\mathrm{N}=154)$ consisted of Hungarian cancer patients, 80 of whom participated in a course focusing on the Simonton method, while 74 of them formed a matched control group. Outcome variables were assessed at baseline, at the end of the training (in the intervention group only), and finally, six months after the intervention. The test battery included the following instruments: Social Support Dimension Scale, Perceived Stress Scale, Hospital Anxiety and Depression Scale, Freiburg Questionnaire on Coping with Illness, Functional Assessment of Cancer Therapy General Scale, Internal-External Locus of Control Scale, the Life Orientation Test, and the items measuring life force from the Profile of Mood States. Results: Only a minor increase in distractive coping emerged in the control group during the follow-up period. In the treatment group however, significant decrease was observed by the end of the 11-week intervention period in scores measuring perceived stress $(p<0.001)$, anxiety $(\mathrm{p}<0.001)$, depression $(\mathrm{p}=0.001)$, and depressive coping $(\mathrm{p}=0.017)$. Further, life force $(\mathrm{p}$ $=0.013)$ and distractive coping scores $(\mathrm{p}=0.017)$ increased significantly. All these positive changes remained present by the end of the follow-up period.

Conclusion: The Simonton method proved to be a useful tool in restoring and promoting the psychological well-being and quality of life of cancer patients. 
Keywords: cancer patients, psychological intervention, Simonton method, effectiveness,

1 well-being, quality of life, coping with illness 


\section{BEVEZETÉS}

Az elmúlt évtizedekben a rákgyógyítás terén komoly elörelépéseket tapasztalhatunk: nemcsak a gyógyult betegek aránya nő, hanem a jó életminőségben élő betegek száma is emelkedik (Bodoky \& Kopper, 2013). A modern sebészeti beavatkozások, kemoterápiás szerek, sugárterápia és biológiai kezelések mellett egyre erősebb igény jelentkezik azonban a betegség lélektani vetületének gyógyítása iránt is. A különféle pszichológiai intervenciókat, egyéni és csoportos terápiákat, pszichoedukációt, az életmódváltást előidéző komplex módszereket egyre több beteg és hozzátartozó keresi, illetve illeszti be a betegséggel való megküzdést segítő programjába a magyar rákbetegek között is.

Ilyen komplex program a Simonton-módszer is, melyet Carl Simonton radiológus és Stefani Mathews-Simonton pszichológus dolgozott ki 1971-ben (Simonton, MatthewsSimonton, \& Creighton, 1978). Ez az intervenció relaxációra épülő öngyógyító imaginációt, az érzelmi egyensúly kialakítását, a betegséggel kapcsolatos szorongás és félelmek, halálfélelem feldolgozását, a jövővel kapcsolatos pozitív célok megalkotását foglalja magába. A módszer részét képezi a rendszeres testmozgás és az egészséges táplálkozás szem előtt tartása is. A Simonton-módszer az elme és az érzelmek teremtő erejére épít, megalkotói elképzelése szerint a gyógyíthatatlan betegek életminőségét, akár élethosszát is befolyásolhatja az eljárás (Simonton és mtsai, 1978).

A módszer elméleti hátterében Selye János felismerése áll, mely kapcsolatot feltételez a stresszhatások és a betegségek kialakulása között, s mely kapcsolat a személyiség típusától függően más-más betegség megjelenését valószínűsíti. Ezt az ideát terjesztette ki a Simontonházaspár, mely szerint, ha az érzelmek és gondolatok képesek hozzájárulni a betegség kialakulásához, akkor felhasználhatjuk öket a gyógyításban is (Achteberg, Simonton, \& Matthews-Simonton, 1977). A Simonton-módszer eredeti célja az immunrendszer stimulálása 
a képzelet segítségével annak érdekében, hogy az megtámadja és megsemmisítse a rákos során a betegek egyéni vagy csoportos foglalkozásokon sajátítják el a progresszív relaxációt, tanulnak meg vizualizációval, képzeletükkel dolgozni. Számba veszik és rendszerezik az életükben jelenlevő stresszhatásokat, érzelmi problémákat, nyugtalanító félelmeket. A feldolgozáshoz, rendezéshez vezetett imaginációra épülő gyakorlatokat alkalmaznak.

A Simonton-házaspár munkáját vizsgáló empirikus eredményeket összegezve az American Cancer Society (Amerikai Rák Társaság) összefoglalójában a módszer pozitívumai között említi, hogy az (1) erősíti a betegekben a betegség feletti kontroll érzését; (2) csökkenti a tehetetlenség érzetét; (3) a relaxáció csökkenti a feszültséget és átmenetileg erősíti a jóllét érzetét; (4) a módszernek nincs negatív mellékhatása; (5) a sztenderd orvosi terápiák mellett is alkalmazható; (6) a betegben kialakuló pozitív és aktív attitüd erősítésével fokozza a betegséggel való megküzdés hatékonyságát (Simonton \& Matthews-Simonton, 1981). Ugyanakkor a társaság jelentése azt is megemlíti, hogy (1) nincs tudományos evidencia a Simonton-módszer ráktúlélést javító hatásáról; (2) nincs bizonyíték arra, hogy a képzelet segítségével a rosszindulatú, rákos folyamat megváltoztatható; (3) mint ahogy arra sem, hogy a stressz csökkentése fejleszti a szervezet rákkal szembeni ellenállását (Simonton \& Matthews-Simonton, 1981).

A módszerhez nagy reményeket füztek a 1970-80-as években. Különösen a gyógyíthatatlannak minősített betegek kezelésében tünt pozitív reményekkel kecsegtető alternatívának (Klisch, 1980). Az intervenció hatékonyságának bizonyítására azonban legjobb tudomásunk szerint mindössze egyetlen klinikai vizsgálatot végeztek 1974 és 1978 között, 245 rákbeteg bevonásával. Az alkalmazott intervenció vezetett imaginációt, az imaginációban kapott képek rajzban való rögzítését, értelmezését, a belső meggyőződések beazonosítását, változtatását, rendszeres testmozgást és táplálkozási útmutatást tartalmazott. A vizsgálat 
kimeneti változóit az életminőség és az élethossz képezte. A főként emlö-, vastagbél- és vizsgálatban szereplő betegek átlagtúlélési idejét az adott betegségcsoport (pl. emlődaganat) egyesült államokbeli átlag túlélési idejével vetették össze. Az így kapott eredmények a túléléssel kapcsolatban ígéretesek voltak, de a módszertani hiányosságok fényében nem tüntek kellően megbízhatónak. A kísérleti csoport részvevőinek betegség-stádiumát és a betegség súlyosságát nem rögzítették, hiányzott az illesztett kontrollcsoport, a vizsgálatba beválogatott betegek jól képzett, erősen motivált, magasan képzett személyek voltak, ami további korlátját képezte az eredmények általánosíthatóságának (Simonton, MatthewsSimonton, \& Sparks, 1980).

A következő évtizedekben a Simonton-módszer túlélést növelö hatásának bizonyítására nem szerveződtek kontrollcsoportos, randomizált vizsgálatok, de a módszer részét képező relaxáció és imagináció hatékonysága beigazolódott (Eller, 1999; Luebbert, Dahme, \& Hasenbring, 2001). Az évek során ezért ezek lassan meghonosodtak a rákbetegek számára szervezett támaszcsoportokban, a szorongás és a szorongást kísérő különféle testi tüneteket csökkentő stresszkezelő foglakozások módszertanában és az egzisztenciális, expresszív alapokra épülő terápiás csoportok tematikájában. Spiegel, Kraemer, Bloom és Gottheil (1989) vizsgálatának tanúsága szerint például előrehaladott emlőrákos nőbetegek egy éven át tartó támaszcsoportjában a relaxáció, imagináció, életmódváltás és az egymásnak nyújtott érzelmi támasz szignifikáns különbségeket hozott a túlélésben a kontrollcsoporttal összehasonlítva az intervenciós csoport javára.

Bár Spiegel és munkatársainak (1989) eredményeit a túlélés terén nem sikerült reprodukálni, e vizsgálat további kutatások sorát motiválta az azonos metodikára épülő támaszcsoportok hatásának vizsgálatára (pl. Kissane és mtsai, 2007), melyek megerősítették a mentális egészség szignifikáns javulását az alkalmazott intervenciók következtében. Ornish, 
korai stádiumú, prosztatarákos férfiak körében illesztette be intervenciós programjába a

progresszív relaxációt, imaginációt. Hathetes, bentlakásos tréningje részét képezte a napi rendszeres relaxáció és a gyógyítás folyamatát megjelenítő imagináció (speciális diéta és napi testmozgás mellett), mely kétéves nyomonkövetéses vizsgálata eredményei szerint a vizsgálatban részt vett férfiak számára feleslegessé tette a hagyományos orvosi kezeléseket (Ornish és mtsai, 2005).

Baider vizsgálataiban a progresszív relaxáció és a vezetett imagináció bizonyult a distressz hatékony mérséklőjének (Baider, Uziely, \& Kaplan De-Nour, 1994). Vizsgálatok további sokasága számolt be az elmúlt évtizedekben a progresszív relaxáció és imagináció kombinációjának lelki egészséget javító hatásáról (pl. Raffe, Schmidt, \& Ernst, 2005; Walker és mtsai, 1999), melyek összegzésekor szisztematikus áttekintő tanulmányukban Newell, Sanson-Fisher és Savolainen (2002) megállapították, hogy a pszichológiai terápiák emelik a rákbetegek betegséggel és kezelésekkel kapcsolatos tájékozottságát, fejlesztik érzelmi alkalmazkodó-képességüket, javítják az életminőséget és a betegséggel való megküzdés sikerességét.

Jelen vizsgálatban a Simonton-módszer lelki egészségre és életminőségre gyakorolt hatását kívántuk elemezni annak érdekében, hogy hozzájáruljunk a módszer hatékonyságvizsgálatának nemzetközi irodalmához, illetve hogy információkat nyújthassunk a hazai daganatos betegek pszichológiai intervenciókkal elérhető lelkiállapot- és életminőségjavulásáról. Az előzőekben említettük, hogy a relaxáció, vezetett imagináció, vizualizáció hogyan épült be az elmúlt évtizedek rákbetegeket segitő foglalkozásainak módszertanába. Saját vizsgálatunkban a Simonton-módszer eredeti felépítését követtük. A 10 foglalkozás során (hetente 1x2 óra) szerepelt a progresszív relaxáció és a képekkel (imagináció, vizualizáció) való munka elsajátitása; a betegség kialakulásában résztvevő, az életmódból fakadó okok feltérképezése; a lezáratlan érzelmi nehézségek feldolgozása, elengedése; 
megbocsájtás; a betegség kiújulásától való félelem, halálfélelem feldolgozása; célállítás, jövő tervezés; egészséges táplálkozás és a rendszeres tesmozgás szükségességének átgondolása. A 11. Alkalom - a csoportfolyamat befejezése után egy hónappal - a gyakorlás során felmerülő problémák és személyes problémák megosztására és megoldására adott lehetőséget.

Feltételeztük, hogy e komplex módszer alkalmazása révén javul az életminőség, csökken a szorongás és a depresszió szintje, erősödik a kontroll-érzet. Mivel a Simontoncsoportokban önkéntesen jelentkező vagy a kezelőorvos által ajánlott személyek vettek részt, így a csoportok a betegség helye, a diagnózis óta eltelt idő, a betegség stádiuma és súlyossága szempontjából is erősen heterogének. Vizsgálatunkban a Simonton-módszer túlélésre gyakorolt hatása ezért nem szerepelt mérési célként.

\section{MÓDSZER}

A vizsgálat protokollját a Fővárosi Önkormányzat Egyesített Szent István és Szent László Kórházának etikai bizottsága hagyta jóvá (engedélyszám: 24/EB/2009). A Simontonmódszer hatékonyságát egy nagyobb szabású vizsgálat keretein belül elemeztük. A Tủzmadár Alapítvány teljes vizsgálati programjában többféle pszichológiai intervenció hatását kutatjuk (többek között egyéni és csoportos terápiák, pszichoedukáció, hatékony kommunikáció, bentlakásos, intenzív, megküzdést segítő tréning kiegészítve dietetikai és testmozgásra irányuló egyéni tanácsadással stb.). A különböző pszichológiai intervenciókon résztvevő daganatos betegek minden esetben azonos kérdőívcsomagot töltöttek ki. Ebből a vizsgálati anyagból emeltük ki jelen tanulmány keretei között a Simonton-tréningre vonatkozó adatokat. A különböző pszichológiai intervenciók hatásvizsgálatainak feldolgozása és eredményeinek összevetése folyamatban van. 


\section{Minta}

\section{Intervenciós csoport}

A résztvevők a Szent László Kórház Onkológiai Centrumában kezelésben részesülő, illetve már tünetmentes periódusban lévő azon daganatos betegek közül kerültek ki, akik 2009 és 2012 tavasza között kapcsolatba kerültek a daganatos betegek pszichoszociális rehabilitációjával foglalkozó Tủzmadár Alapítvánnyal. A Simonton-tréningre a betegek egy tájékoztató beszélgetés után jelentkezhettek. A 10+1 alkalmat magába foglaló tanfolyam heti rendszerességgel, 120 perces csoportfoglalkozások keretei között zajlott. A csoportokat váltakozva a módszerre felkészített és a módszerrel több, mint egy évtizede dolgozó pszichiáter, illetve pszichológus kolléga vezette. A csoportokat vezető két szakember a Simonton-házaspár által kidolgozott protokolt követte. A résztvevők az informált beleegyezést követően a vizsgálati tesztbattériát a tréning előtt, közvetlenül a tréning utolsó foglalkozása után, illetve 6 hónappal ezután is kitöltötték.

Az intervenciós csoportba összesen 80 személy került be; a vizsgálati személyek 17,5\%-a volt férfi. Átlagéletkoruk 54,6 $( \pm 11,2)$ év. A primer daganat által érintett szerv szempontjából 46,8\%-uk emlődaganatos, 13\% vastagbél-daganatos és 7,8\%-nak volt petefészek-daganata. Továbbá 5,2\%-ban tüdőrák fordult elö, a többi daganattípus előfordulása a mintában $5 \%$ alatti volt. A diagnózis óta eltelt átlagos idő a mintában 28,3 $( \pm 43,5)$ hó: a válaszadók 17,1\%-ának volt 3 hónál frissebb a diagnózisa; megjegyezzük azonban, hogy a résztvevők 56,3\%-a nem válaszolt erre a kérdésre. Az első adatfelvételkor az intervenciós csoport 33,8\%-ának volt, 62,2\%-ának nem volt tudomása áttétről, 3,8\% nem válaszolt.

A tréningen részt vett betegek 8,8\%-a volt nőtlen vagy hajadon, szintén $8,8 \%$ élt élettársi kapcsolatban, 53,8\% élt házastársával, 25,1\% vált el vagy élt külön házastársától és 3,8\% volt özvegy. Iskolázottság tekintetében mintánkban a magasabb végzettségüek domináltak: 71,3\%-nak volt felsőfokú végzettsége, 15,0\% rendelkezett gimnáziumi és 6,3\% 
szakközépiskolai érettségivel, $5 \%$ volt szakmunkás és csak $2,5 \%$ végzett nyolc általánost vagy

kevesebbet. A vizsgálatunkban résztvevők legnagyobb része (45\%) nyugdíjas volt. További 20-20\% dolgozott aktívan, illetve volt betegállományban, 10\% részesült rokkantnyugdíjas ellátásban, 1,3\% volt munkanélküli, illetve 3,8\%-nak volt egyéb, a fentiekbe nem sorolható munkavállalói státusza (pl. GYES, háztartásbeli).

A 80 főből 78-an végezték el a tréninget, és 25 résztvevő morzsolódott le a féléves utánkövetés idejére (3. kérdőívét nem küldte vissza). A lemorzsolódási ráta tehát 31,3\% volt. A lemorzsolódottak közül a nyomonkövetés során 7 fő halt meg, 3 fó címe megváltozott, a többiekről nincs semmilyen információnk. A vizsgálatban maradtak és a lemorzsolódottak összevetését a mért változók mentén az 1. táblázat mutatja be. Az adatok szerint a lemorzsolódottak mindössze két változó mentén különböztek szignifikánsan az utánkövetettektől: jobb társas közérzetről számoltak be és kevésbé jellemezte őket depresszív megküzdési stílus. A különbségek nagysága mindkét esetben közepesként interpretálható.

\section{Illesztett kontrollcsoport}

A Szent László Kórház Onkológiai osztályán lehetőségünk nyílt pszichoszociális intervencióinkban az adott időpontig részt nem vevő 74-fös, illesztett kontrollcsoportot is elérnünk. A kontrollcsoport nem és életkor tekintetében volt illesztett a tréningben résztvevő csoporttal. Az intervenciós és a kontrollcsoport összehasonlításának tanúsága szerint (1. táblázat) a kontrollcsoport tagjai kevésbé szorongtak, jobb volt a társas közérzetük, nagyobb mértékü bagatellizáló megküzdés jellemezte őket és gyengébb volt a belsőkontroll-hitük. A különbségek valamennyi esetben kicsinek vagy közepesnek számítanak.

1. táblázat. A kontroll-, valamint az intervenciós csoport utánkövetett és lemorzsolódott tagjainak kiindulási értékei 


\begin{tabular}{|c|c|c|c|c|c|c|}
\hline & $\begin{array}{l}\text { Kontroll- } \\
\text { csoport } \\
(\mathrm{n}=74)\end{array}$ & $\begin{array}{l}\text { Intervenciós } \\
\text { csoport / } \\
\text { utánkövetett } \\
\qquad(\mathrm{n}=55)\end{array}$ & $\begin{array}{l}\text { Intervenciós } \\
\text { csoport / } \\
\text { lemorzsolódott } \\
(n=25)\end{array}$ & $\begin{array}{l}\text { Utánkövetettek } \\
\text { vs. kontroll- } \\
\text { csoport }\end{array}$ & \begin{tabular}{|} 
Utánkövetettek \\
vs. lemor- \\
zsolódottak
\end{tabular} \\
\hline \multicolumn{2}{|l|}{ Életkor } & $54,6(11,5)$ & $54,6(11,2)$ & $54,5(11,2)$ & $\begin{array}{c}\mathrm{t}<0,01 ; \mathrm{p}= \\
0,997 ; \mathrm{d}<0,01\end{array}$ & $\begin{array}{l}\mathrm{t}=-0,03 ; \mathrm{p}= \\
0,973 ; \mathrm{d}<0,01\end{array}$ \\
\hline \multicolumn{2}{|l|}{ Férfi (N, \%) } & $13(17,6)$ & $4(16,0)$ & $10(18,2)$ & $\begin{array}{c}\chi^{2}<0,01 ; p= \\
0,928 ; V<0,08\end{array}$ & $\begin{array}{c}\chi^{2}=0,06 ; p= \\
0,812 ; \mathrm{V}= \\
0,027\end{array}$ \\
\hline \multicolumn{2}{|c|}{ Társas támogatottság } & $10,1(6,58)$ & $11,2(5,60)$ & $10,1(4,59)$ & $\begin{array}{c}\mathrm{t}=-0,95 ; \mathrm{p}= \\
0,347 ; \mathrm{d}=0,18\end{array}$ & $\begin{array}{l}\mathrm{t}=-0,82 ; \mathrm{p}= \\
0,418 ; \mathrm{d}=0,21\end{array}$ \\
\hline \multicolumn{2}{|c|}{ Észlelt stressz } & $27,5(6,31)$ & $29,7(6,01)$ & $27,7(5,34)$ & $\begin{array}{l}t=-1.92 ; p= \\
0,058 ; d=0,36\end{array}$ & $\begin{array}{l}\mathrm{t}=-1,41 ; \mathrm{p}= \\
0,163 ; \mathrm{d}=0,35\end{array}$ \\
\hline \multicolumn{2}{|l|}{ Szorongás } & $6,51(4,32)$ & $8,07(4,07)$ & $8,06(3,90)$ & $\begin{array}{l}t=-2,08 ; p= \\
0,040 ; d=0,37\end{array}$ & $\begin{array}{l}\mathrm{t}=-0,01 ; \mathrm{p}= \\
0,990 ; \mathrm{d}<0,01\end{array}$ \\
\hline \multicolumn{2}{|l|}{ Depresszió } & $5,21(3,97)$ & $5,56(3,61)$ & $5,04(3,62)$ & $\begin{array}{c}\mathrm{t}=-0,51 ; \mathrm{p}= \\
0,609 ; \mathrm{d}=0,09\end{array}$ & $\begin{array}{c}\mathrm{t}=0,60 ; \mathrm{p}= \\
0,552 ; \mathrm{d}=0,14\end{array}$ \\
\hline \multicolumn{2}{|l|}{ Életerő } & $14,4(5,26)$ & $14,1(5,00)$ & $14,5(4,65)$ & $\begin{array}{c}\mathrm{t}=0,35 ; \mathrm{p}= \\
0,729 ; \mathrm{d}=0,06\end{array}$ & $\begin{array}{c}\mathrm{t}=0,34 ; \mathrm{p}= \\
0,734 ; \mathrm{d}=0,08\end{array}$ \\
\hline \multicolumn{2}{|l|}{ Optimizmus } & $44,5(7,82)$ & $44,7(6,91)$ & $46,4(6,57)$ & $\begin{array}{c}\mathrm{t}=-0,18 ; \mathrm{p}= \\
0,855 ; \mathrm{d}=0,03\end{array}$ & $\begin{array}{c}\mathrm{t}=1,01 ; \mathrm{p}= \\
0,315 ; \mathrm{d}=0,25\end{array}$ \\
\hline \multirow{4}{*}{ Életminőség } & $\begin{array}{l}\text { Rossz fizikai } \\
\text { közérzet }\end{array}$ & $7,90(6,63)$ & $6,70(5,42)$ & $6,83(5,58)$ & $\begin{array}{c}\mathrm{t}=-1,08 ; \mathrm{p}= \\
0,282 ; \mathrm{d}=0,20\end{array}$ & $\begin{array}{c}\mathrm{t}=0,10 ; \mathrm{p}= \\
0,923 ; \mathrm{d}=0,02\end{array}$ \\
\hline & Jó társas közérzet & $21,3(5,85)$ & $18,7(5,88)$ & $21,4(3,75)$ & $\begin{array}{c}t=2,49 ; p= \\
0,014 ; d=0,44\end{array}$ & $\begin{array}{c}t=2,46 ; p= \\
0,016 ; d=0,55\end{array}$ \\
\hline & $\begin{array}{l}\text { Rossz érzelmi } \\
\text { közérzet }\end{array}$ & $6,35(5,12)$ & $6,69(3,69)$ & $5,80(3,10)$ & $\begin{array}{c}\mathrm{t}=-0,44 ; \mathrm{p}= \\
0,674 ; \mathrm{d}=0,08\end{array}$ & $\begin{array}{l}\mathrm{t}=-1,05 ; \mathrm{p}= \\
0,297 ; \mathrm{d}=0,26\end{array}$ \\
\hline & $\begin{array}{l}\text { Funkcionális } \\
\text { jóllét }\end{array}$ & $17,2(6,23)$ & $19,0(4,78)$ & $19,0(4,30)$ & $\begin{array}{l}t=-1,84 ; p= \\
0,069 ; d=0,32\end{array}$ & $\begin{array}{l}\mathrm{t}=0,02 ; \mathrm{p}= \\
0,983 ; \mathrm{d}<0,01\end{array}$ \\
\hline Megküzdés & Depresszív & $2,41(0,89)$ & $2,58(0,84)$ & $2,16(0,67)$ & $\mathrm{t}=-1,12 ; \mathrm{p}=$ & $t=-2.18 ; p=$ \\
\hline
\end{tabular}




\begin{tabular}{|c|c|c|c|c|c|}
\hline & $\begin{array}{l}\text { Kontroll- } \\
\text { csoport } \\
(\mathrm{n}=74)\end{array}$ & $\begin{array}{c}\text { Intervenciós } \\
\text { csoport / } \\
\text { utánkövetett } \\
\qquad(\mathrm{n}=55)\end{array}$ & $\begin{array}{c}\text { Intervenciós } \\
\text { csoport / } \\
\text { lemorzsolódott } \\
\text { (n = 25) }\end{array}$ & $\begin{array}{c}\text { Utánkövetettek } \\
\text { vs. kontroll- } \\
\text { csoport }\end{array}$ & $\begin{array}{c}\text { Utánkövetettek } \\
\text { vs. lemor- } \\
\text { zsolódottak }\end{array}$ \\
\hline & & & & 0,$266 ; d=0,20$ & 0,$032 ; d=0,55$ \\
\hline Aktív & $4,16(0,72)$ & $4,05(0,64)$ & $3,93(0,91)$ & $\begin{array}{c}\mathrm{t}=0,86 ; \mathrm{p}= \\
0,394 ; \mathrm{d}=0,16\end{array}$ & $\begin{array}{c}\mathrm{t}=-0,62 ; \mathrm{p}= \\
0,537 ; \mathrm{d}=0,15\end{array}$ \\
\hline Figyelemelterelö & $3,76(0,89)$ & $3,63(0,77)$ & $3,46(1,00)$ & $\begin{array}{c}\mathrm{t}=0,78 ; p= \\
0,436 ; d=0,16\end{array}$ & $\begin{array}{c}\mathrm{t}=-0,82 ; \mathrm{p}= \\
0,418 ; \mathrm{d}=0,19\end{array}$ \\
\hline Vallásos & $2,92(0,97)$ & $2,76(0,82)$ & $2,51(0,79)$ & $\begin{array}{c}\mathrm{t}=0,99 ; \mathrm{p}= \\
0,326 ; \mathrm{d}=0,18\end{array}$ & $\begin{array}{c}\mathrm{t}=-1,23 ; \mathrm{p}= \\
0,221 ; \mathrm{d}=0,31\end{array}$ \\
\hline Bagatellizáló & $3,22(1,14)$ & $2,82(0,82)$ & $2,69(0,91)$ & $\begin{array}{c}t=2,28 ; p= \\
0,024 ; d=0,40\end{array}$ & $\begin{array}{c}\mathrm{t}=-0,60 ; \mathrm{p}= \\
0,548 ; \mathrm{d}=0,15\end{array}$ \\
\hline Belső kontrollhit & $5,62(1,92)$ & $6,36(1,96)$ & $6,32(1,53)$ & $\begin{array}{l}t=-2,00 ; p= \\
0,049 ; d=0,38\end{array}$ & $\begin{array}{c}\mathrm{t}=-0,08 ; \mathrm{p}= \\
0,935 ; \mathrm{d}=0,02\end{array}$ \\
\hline
\end{tabular}

\section{Mérőeszközök}

A demográfiai adatok kérdéssora magába foglalta a beteg nemét, életkorát, iskolai végzettségét és családi állapotát. Rákérdeztünk arra is, hogy egyedül vagy kapcsolatban él, valamint foglalkozási státuszára (aktív dolgozó / betegállományban van / rokkantnyugdíjas / munkanélküli / nyugdíjas / egyéb; pl. GYES).

A személyt körülvevő társas támogatás feltérképezésére a Társas Támogatási Leltárt (Social Support Dimension Scale; Caldwell, Pearson, \& Chin, 1987) használtuk. Ez az egyszerü eszköz a „Betegsége miatt kialakult nehézségeivel kapcsolatban kikre és milyen mértékben számíthat az alábbiak közül?” kérdésre adott válaszokat $(0=$ egyáltalán nem / 1 = keveset $/ 2$ átlagosan / 3 = nagyon) összegzi. A potenciális támogatók lehetnek például 
szülők, gyermekek, házastárs (familiáris társas támogatás) vagy nem-családtag segítők:

munkatárs, szomszéd, egyházi csoport, civil szervezet (non-familiáris társas támasz).

A pszichológiai változók közül a stressz-szint mérésére az Észlelt Stressz Kérdőív (Cohen, Kamarck, \& Mermelstein, 1983) 10-tételes magyar változatát (Stauder \& Konkolÿ Thege, 2006) használtuk, melynek megbízhatósága kitűnőnek bizonyult a jelen mintában is (Cronbach-alfa: 0,86). A szorongás és a depresszió mérésére a Kórházi Szorongás és Depresszió Skála (Hospital Anxiety and Depression Scale - HADS; Zigmond \& Snaith, 1983) magyar változatát (Muszbek és mtsai, 2006) alkalmaztuk. Mind a szorongásra, mind a depresszióra vonatkozó, 7-7 itemet tartalmazó skála belső megbízhatósága jó volt (Cronbachalfa mindkét skálánál: 0,84).

A megküzdési módok feltérképezésére a Freiburgi Betegség-feldolgozási Kérdőív (Freiburger Fragebogen zur Krankheitsverarbeitung - Muthny, 1989) rövidített, magyar változatát (Tiringer és mtsai, 2011) alkalmaztuk. A kérdőív ötféle megküzdési módot különít el: depresszív-rezignált (5 tétel; Cronbach-alfa: 0,69), aktív-problémaorientált (5 tétel; Cronbach-alfa: 0,62), önbátorító-figyelemelterelő (5 tétel; Cronbach-alfa: 0,72), vallásosértelemkereső (5 tétel; Cronbach-alfa: 0,52) és bagatellizáló-vágyteljesítő (3 tétel; Cronbachalfa: 0,53$)$.

Az életminőség vizsgálatára a FACT-kérdőív általános változatát (General Version of the Functional Assessment of Cancer Therapy Scale; Cella és mtsai, 1993) használtuk. A mérőeszköz az összpontszámon kívül különböző életminőség-domainekről (fizikai, funkcionális, társas és érzelmi jóllét) szolgáltat rákbetegekre nézve specifikus információt. Mind a teljes skála (Cronbach-alfa: 0,90), mind az egyes alskálák belső megbízhatósága jó volt (Cronbach-alfa rendre: 0,$85 ; 0,78 ; 0,81 ; 0,84)$.

A kontrollhely mérésére (ami csak az első időpontban történt meg) a klasszikus Rotter-féle Külső-belső Kontrollhit Kérdőív (Rotter, 1966) magyar verzióját (Oláh, 1982) 
használtuk, mely a személy élete történései fölötti kontrollhitének külső vagy belső voltát optimizmus mérésére az Életszemlélet-tesztet (Life Orientation Test, Scheier \& Carver, 1985) használtuk. A 12-tételes mérőeszköz belső megbízhatósága elfogadható volt (Cronbach-alfa: 0,72). Az energetizáltság mértékét a POMS (Profile of Mood States; Curran, Andrykowski, \& Studts, 1995) rövidített változatának életerőt mérő tételeinek segítségével becsültük meg. Ennek a szintén hat-tételes mérőeszköznek kitűnő belső megbízhatósága volt a jelen mintában (Cronbach-alfa: 0,92).

\section{Statisztikai eljárások}

A leíró statisztikai elemzések során átlagokat, szórásokat és százalékos gyakorisági arányokat számítottunk. A mérőeszközök megbízhatóságának kimutatására Cronbach-alfamutatókat számoltunk. Az intervenció közben lemorzsolódott és bennmaradt csoport eredményeinek, illetve a vizsgálati és kontrollcsoport alapértékeinek összevetésére khinégyzet próbát, illetve független mintás t-próbát használtunk. A hatásméret kifejezésére Cramer-féle V-értéket (khi-négyzet próba), illetve Cohen-féle d-értékeket (t-próba) számoltunk.

A vizsgált folytonos pszichológiai változóknak a Simonton-tréning három periódusában való különbségét - a második és a harmadik felvételkor kapott adatokat is az első felvételhez hasonlítva - összetartozó-mintás t-próbával vizsgáltuk. A hatásméret kifejezésére ismét Cohen-féle d-értéket számoltunk. A d-értékeket egy online alkalmazás használatával számítottuk ki, az összes többi statisztikai elemzést az SPSS Statistics for Windows 21-es verziójával végeztük el. 


\section{EREDMÉNYEK}

Mért változóink leíró statisztikáit mindhárom mérési alkalommal, illetve az intervenció során és az utánkövetés során bekövetkezett változásokra vonatkozó statisztikai elemzések részleteit a 2. táblázat tartalmazza. Az adatok azt mutatják, hogy az intervenció befejeztére a résztvevők körében szignifikánsan csökkent a szorongás, a depresszió, az észlelt stressz szintje, és szintén szignifikáns mértékben nött körükben az életerő. Nem történt szignifikáns változás viszont az optimizmus, az életminőség-dimenziók és a legtöbb megküzdési stílus tekintetében. Ez utóbbiak közül csak a depresszív megküzdés előfordulása csökkent, a figyelemelterelő copingé pedig nőtt. A szignifikáns változások hatásmérete kis, illetve közepes nagyságú volt (2. táblázat).

A féléves utánkövetés adatai azt mutatják, hogy az intervenció révén kialakult pozitív változások nagyobb része hosszabb távon is megmaradt (2. táblázat). A Simonton-tréningen résztvettek körében a kiindulási értékeknél továbbra is szignifikánsan alacsonyabb maradt a szorongás, a depresszió és az észlelt stressz szintje. Szintén szignifikáns maradt az az életerő körükben mért növekedése, valamint a depresszív megküzdés csökkenése és a figyelemelterelő coping növekedése. Ezen felül érdekes módon megjelent egy új változás is az utánkövetés idején: az aktív, problémafókuszú megküzdés szintje szignifikáns csökkenést mutatott fél év elteltével.

A kontrollcsoport esetében mindössze két adatfelvétel történt: kiinduláskor és attól számított fél év elteltével. Az e csoportba tartozó betegek esetében a figyelemelterelő megküzdésben tapasztaltunk egyedül szignifikáns, enyhe növekedést. A többi mért változó tekintetében nem mutattak változást a kontrollcsoporthoz tartozó daganatos betegek (2. táblázat). 
2. táblázat. A kontroll-, valamint az intervenciós csoport utánkövetési adatai, illetve a kiindulási értékekhez képesti változásokkal kapcsolatos statisztikai próbák értékei

\begin{tabular}{|c|c|c|c|c|c|c|c|}
\hline & \multicolumn{2}{|c|}{ Kontrollcsoport } & \multicolumn{4}{|c|}{ Intervenciós csoport } \\
\hline & & \begin{tabular}{|} 
Utánkövetési \\
értékek \\
[átlag \\
(szórás)]
\end{tabular} & $\begin{array}{l}\text { Változás a } \\
\text { kiindulási } \\
\text { értékhez } \\
\text { képest }\end{array}$ & $\begin{array}{c}\text { Intervenció } \\
\text { utáni értékek } \\
\text { [átlag } \\
\text { (szórás)] }\end{array}$ & $\begin{array}{l}\text { Változás a } \\
\text { kiindulási } \\
\text { értékhez } \\
\text { képest }\end{array}$ & $\begin{array}{c}\text { Utánkövetési } \\
\text { értékek } \\
\text { [átlag } \\
\text { (szórás)] }\end{array}$ & $\begin{array}{c}\text { Változás a } \\
\text { kiindulási } \\
\text { értékhez } \\
\text { képest }\end{array}$ \\
\hline \multicolumn{2}{|c|}{ Társas támogatottság } & $11,3(5,68)$ & $\begin{array}{c}\mathrm{t}=0,16 ; \mathrm{p}= \\
0,876 ; \mathrm{d}= \\
0,02\end{array}$ & $11,5(5,10)$ & $\begin{array}{c}\mathrm{t}=-1,53 ; \mathrm{p}= \\
0,131 ; \mathrm{d}= \\
0,14\end{array}$ & $11,5(5,36)$ & $\begin{array}{c}\mathrm{t}=-0,83 ; \mathrm{p}= \\
0,411 ; \mathrm{d}= \\
0,08\end{array}$ \\
\hline \multicolumn{2}{|c|}{ Észlelt stressz } & $28,7(7,63)$ & $\begin{array}{c}\mathrm{t}=-1.02 ; \mathrm{p}= \\
0,319 ; \mathrm{d}= \\
0,18\end{array}$ & $26,6(5,99)$ & $\begin{array}{c}\mathrm{t}=3,74 ; \\
\mathrm{p}<0,001 ; \mathrm{d}= \\
0,42\end{array}$ & $27,0(6,11)$ & $\begin{array}{c}\mathrm{t}=3,17 ; \mathbf{p}= \\
0,003 ; \mathrm{d}= \\
0,42\end{array}$ \\
\hline \multicolumn{2}{|l|}{ Szorongás } & $6,30(4,91)$ & $\begin{array}{c}\mathrm{t}=0,77 ; \mathrm{p}= \\
0,451 ; \mathrm{d}= \\
0,12\end{array}$ & $6,38(4,12)$ & $\begin{array}{c}t=3,95 ; \\
p<0,001 ; d= \\
0,42\end{array}$ & $6,31(4,19)$ & $\begin{array}{c}t=3,59 ; p= \\
0,001 ; d= \\
0,43\end{array}$ \\
\hline \multicolumn{2}{|l|}{ Depresszió } & $5,60(5,31)$ & $\begin{array}{c}t=-0,16 ; p= \\
0,873 ; d= \\
0,02\end{array}$ & $4,18(3,12)$ & $\begin{array}{c}t=3,61 ; p= \\
0,001 ; d= \\
0,36\end{array}$ & $4,69(3,38)$ & $\begin{array}{c}t=2,06 ; p= \\
0,044 ; d= \\
0,25\end{array}$ \\
\hline \multicolumn{2}{|l|}{ Életerő } & $14,3(6,81)$ & $\begin{array}{c}\mathrm{t}=-0,13 ; \mathrm{p}= \\
0,894 ; \mathrm{d}= \\
0,02\end{array}$ & $15,8(4,94)$ & $\begin{array}{c}t=-2,56 ; p \\
=0,013 ; d= \\
0,35\end{array}$ & $15,7(4,84)$ & $\begin{array}{c}t=-2,01 ; p= \\
0,049 ; d= \\
0,31\end{array}$ \\
\hline \multicolumn{2}{|l|}{ Optimizmus } & $44,0(11,0)$ & $\begin{array}{c}\mathrm{t}=0,27 ; \mathrm{p}= \\
0,793 ; \mathrm{d}= \\
0,04\end{array}$ & $46,0(7,07)$ & $\begin{array}{c}\mathrm{t}=-1,35 ; \mathrm{p}= \\
0,182 ; \mathrm{d}= \\
0,13\end{array}$ & $45,6(7,31)$ & $\begin{array}{c}\mathrm{t}=-1,07 ; \mathrm{p}= \\
0,291 ; \mathrm{d}= \\
0,13\end{array}$ \\
\hline \multirow[t]{2}{*}{ Életminőség } & $\begin{array}{l}\text { Rossz fizikai } \\
\text { közérzet }\end{array}$ & $6,37(6,02)$ & $\begin{array}{c}\mathrm{t}=1,40 ; \mathrm{p}= \\
0,174 ; \mathrm{d}= \\
0,19\end{array}$ & $6,28(5,28)$ & $\begin{array}{c}\mathrm{t}=0,80 ; \mathrm{p}= \\
0,425 ; \mathrm{d}= \\
0,09\end{array}$ & $5,65(4,91)$ & $\begin{array}{c}\mathrm{t}=1,46 ; \mathrm{p}= \\
0,149 ; \mathrm{d}= \\
0,20\end{array}$ \\
\hline & $\begin{array}{l}\text { Jó társas } \\
\text { közérzet }\end{array}$ & $20,4(5,96)$ & $\begin{array}{c}\mathrm{t}=0,33 ; \mathrm{p}= \\
0,748 ; \mathrm{d}=\end{array}$ & $18,4(6,04)$ & $\begin{array}{c}t=1,87 ; p= \\
0,066 ; d=\end{array}$ & $18,5(5,70)$ & $\begin{array}{c}\mathrm{t}=0,22 ; \mathrm{p}= \\
0,829 ; \mathrm{d}=\end{array}$ \\
\hline
\end{tabular}




\begin{tabular}{|c|c|c|c|c|c|c|c|}
\hline & & Kontroll & lcsoport & & Intervenci & ós csoport & \\
\hline & & $\begin{array}{l}\text { Utánkövetési } \\
\text { értékek } \\
\text { [átlag } \\
\text { (szórás)] }\end{array}$ & $\begin{array}{l}\text { Változás a } \\
\text { kiindulási } \\
\text { értékhez } \\
\text { képest }\end{array}$ & $\begin{array}{c}\text { Intervenció } \\
\text { utáni értékek } \\
\text { [átlag } \\
\text { (szórás)] }\end{array}$ & $\begin{array}{l}\text { Változás a } \\
\text { kiindulási } \\
\text { értékhez } \\
\text { képest }\end{array}$ & $\begin{array}{c}\text { Utánkövetési } \\
\text { értékek } \\
\text { [átlag } \\
\text { (szórás)] }\end{array}$ & $\begin{array}{l}\text { Változás a } \\
\text { kiindulási } \\
\text { értékhez } \\
\text { képest }\end{array}$ \\
\hline & & & 0,04 & & 0,19 & & 0,03 \\
\hline & $\begin{array}{l}\text { Rossz érzelmi } \\
\text { közérzet }\end{array}$ & $6,91(5,61)$ & $\begin{array}{c}\mathrm{t}=-1,20 ; \mathrm{p}= \\
0,241 ; \mathrm{d}= \\
0,16\end{array}$ & $5,81(4,18)$ & $\begin{array}{c}\mathrm{t}=1,27 ; \mathrm{p}= \\
0,207 ; \mathrm{d}= \\
0,15\end{array}$ & $5,76(3,69)$ & $\begin{array}{c}t=1,389 ; p= \\
0,172 ; d= \\
0,25\end{array}$ \\
\hline & $\begin{array}{l}\text { Funkcionális } \\
\text { jóllét }\end{array}$ & $17,7(6,61)$ & $\begin{array}{c}\mathrm{t}=-0,87 ; \mathrm{p}= \\
0,392 ; \mathrm{d}= \\
0,12\end{array}$ & $19,0(4,91)$ & $\begin{array}{c}\mathrm{t}=-0,10 ; \mathrm{p}= \\
0,923 ; \\
\mathrm{d}<0,01\end{array}$ & $19,5(5,18)$ & $\begin{array}{c}t=1,94 ; p= \\
0,058 ; d= \\
0,11\end{array}$ \\
\hline & Depresszív & $2,48(0,84)$ & $\begin{array}{c}\mathrm{t}=0,26, \mathrm{p}= \\
0,795, \mathrm{~d}= \\
0,05\end{array}$ & $2,24(0,82)$ & $\begin{array}{c}\mathrm{t}=2,45 ; p= \\
0,017 ; d= \\
0,27\end{array}$ & $2,30(0,80)$ & $\begin{array}{c}t=2,51 ; p= \\
0,015 ; d= \\
0,34\end{array}$ \\
\hline & Aktív & $4,29(0,65)$ & $\begin{array}{c}\mathrm{t}=0,53, \mathrm{p}= \\
0,601, \mathrm{~d}= \\
0,08\end{array}$ & $4,02(0,71)$ & $\begin{array}{c}\mathrm{t}=-0,22 ; p= \\
0,826 ; d= \\
0,02\end{array}$ & $3,84(0,73)$ & $\begin{array}{c}t=2,63 ; p= \\
0,011 ; d= \\
0,31\end{array}$ \\
\hline Megküzdés & Figyelemelterelö & $4,08(0,76)$ & $\begin{array}{c}t=-2,68, p= \\
0,013, d= \\
0,35\end{array}$ & $3,76(0,64)$ & $\begin{array}{c}t=-2,10 ; p \\
=0,039, d= \\
0,26\end{array}$ & $3,89(0,71)$ & $\begin{array}{c}t=-2,45 ; p= \\
0,018 ; d= \\
0,34\end{array}$ \\
\hline & Vallásos & $2,82(0,77)$ & $\begin{array}{c}\mathrm{t}=0,93, \mathrm{p}= \\
0,362, \mathrm{~d}= \\
0,16\end{array}$ & $2,75(0,73)$ & $\begin{array}{c}\mathrm{t}=-0,91 ; \mathrm{p}= \\
0,365 ; \mathrm{d}= \\
0,10\end{array}$ & $2,89(0,77)$ & $\begin{array}{c}\mathrm{t}=-1,41 ; \mathrm{p}= \\
0,164 ; \mathrm{d}= \\
0,16\end{array}$ \\
\hline & Bagatellizáló & $3,11(1,11)$ & $\begin{array}{c}\mathrm{t}=0,63, \mathrm{p}= \\
0,537, \mathrm{~d}= \\
0,15\end{array}$ & $2,87(0,86)$ & $\begin{array}{c}\mathrm{t}=-0,85 ; \mathrm{p}= \\
0,396 ; \mathrm{d}= \\
0,10\end{array}$ & $2,68(0,83)$ & $\begin{array}{c}\mathrm{t}=1,04 ; \mathrm{p}= \\
0,304, \mathrm{~d}= \\
0,17\end{array}$ \\
\hline
\end{tabular}

\section{DISZKUSSZIÓ}


Az 1970-80-as években nagy érdeklődés övezte a test-lélek egységét szem előtt tartó, 
A fenti eredmények alapján elmondhatjuk, hogy az eredeti, komplex Simonton-tréning

hatékonynak modható a daganatos betegek pszichológiai jól-létének fokozására és fenntartására, hisz az intervenció hatása fél év múltán is számottevő, míg az illesztett kontrollcsoport mutatói ugyanennyi idő elteltével gyakorlatilag változatlanok maradtak, kivéve a figyelemelterelő megküzdést, mely szignifikáns növekedést mutatott a félévvel későbbi mérések során. Eredményeink támogatják azon következtetéseket, melyek szerint a komplex pszichoterápiás módszerek dagantos betegek körében hatékonyak - a pszichológiai egészség terén legalábbis biztosan (Coyne, Hanisch, \& Palmer, 2007; Kissane és mtsai, 2007).

Vizsgálatunknak és levont következtetéseinknek ugyanakkor a jelen kutatás természeténél és módszertanánál fogva számos korlátja is van. A klinikai mintát használó, komplex intervenciót célzó, hosszabb utánkövetésü hatásvizsgálatok limitációi itt is érvényesülnek. Az ilyen jellegü intervencióra jelentkezők pszichológiai jellemzői eleve nem tekinthetőek populációs átlagértékeknek (,,a magyar daganatosok”): erős motiváció és megfelelő külső körülmények, illetve szervezés (pl. fővárosközeli lakhely vagy a bejárás megszervezése) szükséges a programon való részvételhez - a randomizáció és a kettős vak elrendezés tehát nem valósítható meg. Mindazonáltal a kontrollcsoport bevonásával igyekeztünk ezt a szelekciós torzítást kompenzálni.

Ezen felül a relatíve kis elemszám további csoportosításra - például a daganat típusa, stádiuma vagy akár nemek szerint - nem ad lehetőséget, ha az elemzések statisztikai erejéről nem akarunk lemondani. A nyomonkövetésben nem szerepel a napi gyakorlások követése, így annak a hétköznapokba való beépüléséről, illetve a gyakorlás mennyiségének a mért változókra kifejtett hatásáról nincs információnk. A megküzdési módok feltérképezésére szolgáló Freiburgi Betegség-feldolgozási Kérdőív számos skálájának optimálisnál alacsonyabb Cronbach-alfa-értéke csökkenti továbbá az ezzel a mérőeszközzel gyűjtött adatok megbízhatóságát. 
Végül, a csoportokra jelentkezők 71,3\%-a felsőfukú végzettségü, míg a középiskolainál alacsonyabb végzettségüek megjelenése a vizsgálati mintában csupán 7,5\%. A továbbiakban ezért szükséges volna a program szélesebb körü kiterjesztése és hatékonyságának vizsgálata e nagyobb populáción. Magasabb résztvevőszám és kontrollcsoport-létszám elérése, illetve a tréning által elsajátítható életmódváltás (pl. rendszeres testmozgás beépítése, a táplálkozási szokások változásának mérése, napi gyakorlás követése) és a résztvevők állapotának hosszabb távú és még szélesebb körü monitorozása szintén kívánatos volna. Különösen fontos feladat az alacsonyabb képzettségü betegek körében a pszichológiai kultúra erősítése, a pszichológiai intervenciókkal kapcsolatos ismeretek terjesztése, annak közvetítése, hogy a betegséget kísérő pszichoszociális problémákat nem csak elszenvedhetik, hanem aktívan változtathatnak is rajtuk.

\section{KÖVETKEZTETÉSEK}

Összegzésképp elmondhatjuk, hogy a Simonton-tréning komplex eszköztárával, megfelelően képzett szakember vezetésével valóban hasznos segítséget nyújt, és pozitív, maradandó hatásokat eredményez a daganatos betegek pszichés egészsége szempontjából. Hatására javul a lelki egészség, növekszik az életerő, csökken a depresszív megküzdés, mely lehetővé teszi a betegséghez való jobb alkalmazkodást. A Simonton-tréning alkalmazását ezért kiegészítő pszichológiai intervencióként, életmód-változtatást segítő beavatkozásként javasoljuk a betegséggel aktívan küzdőknek. Végezetül álljon itt egy idézet a számos visszajelzésből, melyet a csoportok résztvevőitől kaptunk: „, A Simonton-tanfolyamon eszközt kaptam, hogy én is tehessek valamit a gyógyulásomért, ne csak kiszolgáltatottan várjam mások segítségét. Módszert, hogy nyugodtabban, harmonikusabban éljek, reményt, hogy meg 
lehet gyógyulni. Felhívta a figyelmemet, hogy a saját életünkért nekünk is kell tenni. Az

2 életemet én befolyásolom, én irányithatom." 


\section{IRODALOM}

Achteberg, J., Simonton, O.C., \& Matthews-Simonton, S. (1977). Stress, psychological factors, and cancer: An annotated collection of readings from the professional literature. Fort Worth: New medicine Press

Baider, L., Uziely, B., \& Kaplan De-Nour, A. (1994). Progressive muscle relaxation and guided imagery in cancer patients. General Hospital Psychiatry, 16(5), 340-347.

Bodoky, Gy., Kopper L. (2013). Tüdő és mediasztinális onkológia. Budapest: Semmelweis Kiadó

Caldwell, R.A., Pearson, J.L., \& Chin, R.J. (1987). Stress-Moderating Effects. Social Support in the Context of Gender and Locus of Control. Personality and Social Psychology Bulletin, 13(1), 5-17.

Cella, D.F., Tulsky, D.S., Gray, G., Sarafian, B., Linn, E., Bonomi, A., et al. (1993). The Functional Assessment of Cancer Therapy Scale: Development and validation of the general measure. Journal of Clinical Oncology, 11, 570-579.

Cohen, S., Kamarck, T., \& Mermelstein, R. (1983). A global measure of perceived stress. Journal of Health and Social Behavior, 24, 385-396.

Coyne, J.C., Hanisch, L.J., \& Palmer, S.C. (2007). Psychotherapy does not promote survival (Kissane et al., 2007): now what? Psycho-Oncology, 16, 1050-1052.

Curran, S.L., Andrykowski, M.A., \& Studts, J.L. (1995). Short Form of the Profile of Mood States (POMS-SF): Psychometric information. Psychological Assessment, 7(1), 80-83.

Eller, L.S. (1999). Guided imagery interventions for symptom management. Annual Review of Nursing Research, 17(1), 57-84.

Holland, J.C, Breitbart, W., \& Jacobsen, P. B. (1998). Handbook of Psycho-Oncology. New York: Oxford University Press 
Kissane, D.W., Grabsch, B., Clarke, D.M., Smith, G.C., Love, A.W., Bloch, S., et al. (2007). Supportive-expressive group therapy for women with metastatic breast cancer: Survival and psychosocial outcome from a randomized controlled trial. Psycho-Oncology, 16, 277-286.

Klisch, M. (1980). The Simonton method of visualisation: Nursing implications and a patient's perspective. Cancer Nursing, 3(4), 295-300.

Luebbert, K., Dahme, B., \& Hasenbring, M. (2001). The effectiveness of relaxation training in reducing treatment-related symptoms and improving emotional adjustment in acute non-surgical cancer treatment: A meta-analytical review. Psycho-Oncology, 10, 490502.

Muszbek, K., Szekely, A., Balogh, É., Molnár, M., Rohánszky, M., Ruzsa, Á., et al. (2006). Validation of the Hungarian Translation of Hospital Anxiety and Depression Scale. Quality of Life Research, 15, 761-766.

Muthny, F.A. (1989). Freiburger Fragebogen zur Krankheitsverarbeitung. Göttingen: Hogrefe

Newell, S.A., Sanson-Fisher, R.W., \& Savolainen, N.J. (2002). Systematic review of psychological therapies for cancer patients: Overview and recommendations for future research. Journal of the National Cancer Institute, 94(8), 558-584.

Oláh, A. (1982). Kérdölves módszerek a külső-belsö kontroll attitüd vizsgálatára. Budapest: Országos Pedagógiai Intézet

Ornish, D., Weidner, G., Fair, W.R., Marlin, R., Pettengill, E.B., Raisin, C.J., et al. (2005). Intensive lifestyle changes may affect the progression of prostate cancer. The Journal of Urology, 174, 1065-1070.

Raffe, L., Schmidt, K., \& Ernst, E. (2005). A systematic review of guided imagery as an adjuvant cancer therapy. Psycho-Oncology, 14, 607-617. 
Rotter, J.B. (1966). Generalized expectancies for internal versus external control of reinforcement. Psychological Monographs, 80(1), 1-28.

Scheier, M.F., \& Carver, C.S. (1985). Optimism, coping, and health: Assessment and implications of generalized outcome expectancies. Health Psychology, 4(3), 219-247.

Simonton, O.C., \& Matthews-Simonton, S. (1981). Cancer and stress: counselling the cancer patient. The Medical Journal of Australia, 1(13), 679-683.

Simonton, O.C., Matthews-Simonton, S., \& Creighton, J. (1978). Getting well again: A stepby-step, self-help guide to overcoming cancer for patients and their families. Los Angeles: JP Tarcher Inc

Simonton, C.O., Matthews-Simonton, S., \& Sparks, F.T. (1980). Psychological intervention in the treatment of cancer. Psychosomatics, 21(3), 226-233.

Spiegel, D., Kraemer, H., Bloom, J., \& Gottheil, E. (1989). Effect of psychosocial treatment on survival of patients with metastatic breast cancer. The Lancet, 334(8668), 888-891.

Stauder, A., \& Konkolÿ Thege, B. (2006). Az Észlelt Stressz Kérdőív (PSS) magyar verziójának jellemzői. Mentálhigiéné és Pszichoszomatika, 7, 203-216.

Tiringer, I., Simon, A., Németh, K., Bánki, C., Molnár, E., Szamosi, E., et al. (2011). A Freiburgi Betegségfeldolgozási Kérdőív rövidített változatának (FKV-LIS) hazai adaptációja. A megerősítő faktoranalízis eredményei. Magyar Pszichológiai Szemle, 66, $631-667$.

Walker, L.G., Walker, M.B., Ogston, K., Heys, S.D., Ah-See, A.K., Miller, I.D., et al. (1999). Psychological, clinical and pathological effects of relaxation training and guided imagery during primary chemotherapy. British Journal of Cancer, 80(1-2), 262-268.

Zigmond, A.S., \& Snaith, R.P. (1983). The Hospital Anxiety and Depression Scale. Acta Psychiatrica Scandinavica, 67, 361-370. 